\title{
PERAN KEPALA SEKOLAH SEBAGAI MANAJER DALAM MENINGKATKAN MUTU PENDIDIKAN DI SMP 1 CILAWU GARUT
}

\author{
Yogi Irfan Rosyadi, Pardjono \\ Yayasan Pendidikan Rusyani Hikmatul Rosyad, Univesitas Negeri Yogyakarta \\ gonzalezpalsu@yahoo.co.id, pardjono@uny.ac.id
}

\begin{abstract}
Abstrak
Penelitian ini bertujuan untuk: (1) mendeskripsikan strategi kepala sekolah dalam merencanakan program, mengorganisasikan, menggerakkan dan mengawasi program sekolah untuk meningkatkan mutu pendidikan di SMP 1 Cilawu; (2) mendeskripsikan penghambat dalam meningkatkan mutu pendidikan. Penelitian ini merupakan studi kasus dengan menggunakan pendekatan kualitatif. Subjek penelitian adalah pendidik dan tenaga kependidikan. Hasil dari penelitian ini menunjukkan kepala sekolah sebagai seorang manajer berperan: (1) merencanakan program dengan merinci kebutuhan pendidik dan tenaga kependidikan yang akan menjalankan tugas, merencanakan kurikulum yang akan dijalankan, merencanakan kebijakan penambahan mata pelajaran bimbingan konseling dengan waktu dua jam per minggu; (2) membuat struktur organisasi yang melibatkan orang tua murid melalui komite sekolah dan melengkapi sarpras yang dibutuhkan; (3) Memberi contoh yang baik dan tenang dalam bekerja, memberi motivasi dan penghargaan terhadap personilnya baik moril maupun materil, meningkatan kesejahteraan, mengikutsertakan pendidik dan tenaga kependidikan dalam diklat-diklat dan memotivasi guru senior agar memiliki semangat life long education; (4) mengawasi output, PBM, dan peserta didik mulai dari proses penerimaan sampai selesai sekolah. (5) adapun hambatan yang dialami adalah adanya personil yang masih tidak disiplin, kurangnya komunikasi antara kepala sekolah dengan sebagian personil.
\end{abstract}

Kata kunci: kepala sekolah, perencanaan, pengorganisasian, penggerakkan, dan monitoring

\section{ROLES OF THE PRINCIPAL AS A MANAGER IN THE IMPROVEMENT OF THE QUALITY OF EDUCATION AT SMP 1 CILAWU, GARUT REGENCY}

\author{
Yogi Irfan Rosyadi, Pardjono \\ Yayasan Pendidikan Rusyani Hikmatul Rosyad, Univesitas Negeri Yogyakarta \\ gonzalezpalsu@yahoo.co.id, pardjono@uny.ac.id
}

\begin{abstract}
This study aims to: (1) describe the principal's strategies to plan, organize, actuate, and control the school programs to improve the quality of education at SMP 1 Cilawu; and (2) describe constraints in the improvement of the quality of education. This was a case study with qualitative approach. The research subjects included teachers and educational personnel. The results of the study used the principal's as a manager: (1) plans programs by specifying the needs for teachers and educational personnel who will carry out duties, programs in the form of policies and the curriculum that will be implemented, and policies to add the time slot for the guidance and counseling subject by two hours a week; (2) makes an organizational structure by involving students' parents through the school committee and completing infrastructure facilities that the school needs; (3) gives examples of how to work well and calmly, motivation, and rewards to the personnel morally and materially, improves welfare, sends teachers and educational personnel to trainings, and motivates senior teachers to have spirit of lifelong education; and (4) controls the output, teaching and learning processes, and students from the enrolment to the graduation. (5) The constraints include the facts that there are personnel who are not disciplined, there is a lack of communication between the principal and some of the personnel, and the school operation aid funds do not match the school's needs.
\end{abstract}

Keywords: principal, planning, organizing, leading, and monitoring. 



\section{Pendahuluan}

Pendidikan merupakan kebutuhan manusia yang sangat penting dalam kehidupan manusia itu sendiri. Manusia pada hakikatnya tak hanya akan tergantung pada alam tanpa adanya pengaruh lain. Dalam proses itulah muncul pengaruh yang akan didapat oleh manusia dari manusia lain yang membawa perubahan sikap atas manusia yang dipengaruhinya.

Sesuai dengan hal di atas jelas bahwa manusia itu memerlukan sebuah pendidikan, pendidikan merupakan proses untuk mengubah manusia dari kondisi tertentu terhadap kondisi lainnya. Maka dengan pendidikan itu perubahan akan nampak dalam proses perubahan pikiran manusia, dari tidak mengerti menjadi mengerti, dari tidak mengetahui menjadi mengetahui, karena pendidikan adalah suatu hal yang mutlak yang harus dipenuhi dalam upaya untuk meningkatkan taraf hidup manusia, agama, dan khususnya bangsa Indonesia agar tidak sampai tertinggal dengan bangsa lain.

Hal itu sejalan dengan pengertian pendidikan yang tercantum dalam UU Sisdiknas No. 20 tahun 2003 pasal 1 yang berbunyi "Pendidikan adalah usaha sadar dan terencana untuk mewujudkan suasana belajar dan proses pembelajaran agar peserta didik secara aktif mengembangkan potensi dirinya untuk memiliki kekuatan spiritual keagamaan, pengendalian diri, kepribadian, kecerdasan, akhlak mulia, serta keterampilan yang diperlukan dirinya, masyarakat, bangsa dan negara".

Karena itu sistem pendidikan harus mampu menjamin pemerataan kesempatan pada peningkatan mutu serta relevansi dan efisiensi manajemen pendidikan untuk menghadapi tantangan sesuai dengan tuntutan perubahan kehidupan di dalam negeri maupun luar negeri, sehingga diperlukan perubahan pendidikan secara terencana, terarah dan berkesinambungan. Oleh karena itu pendidikan memerlukan penataan yang professional, hal tersebut diperlukan personal yang mampu dan tangguh. Dari hal inilah yang kita sebut sebagai pemimpin pendidikan/kepala sekolah. Se- orang kepala sekolah tidak saja dituntut menguasai teori kepemimpinan tetapi harus juga terampil menerapkannya dalam situasi yang praktis diera kerja.

Kepala sekolah adalah pimpinan pendidikan yang mempunyai peranan penting dalam mengembangkan lembaga pendidikan, yaitu sebagai pemegang kendali di lembaga pendidikan. Dalam hal ini peranan kepala sekolah harus digerakan sedemikian rupa sesuai dengan perannya dalam meningkatkan mutu pendidikan yaitu sebagai manajer sehingga dapat mempengaruhi kalangan staf guru, baik itu secara langsung maupun tidak langsung. Di samping itu, kepala sekolah juga mempunyai peranan yang sangat besar dalam mengembangkan kualitas pendidikan di lembaga pendidikan tersebut.

Sejalan dengan itu, peranan kepala sekolah sangat berpengaruh dalam pertumbuhan dan perkembangan pendidikan yakni untuk meningkatkan sumber daya manusia dan mutu pendidikan. Kepala sekolah dan guru beserta tenaga kependidikan lainnya dituntut untuk berperan aktif untuk meningkatkan pertumbuhan dan perkembangan kualitas profesinya dengan harapan memperoleh pengetahuan baru. Kepala Sekolah juga bertindak sebagai seorang pendidik yang bertanggung jawab terhadap manajemen sekolah.

Keberhasilan suatu lembaga pendidikan sangat tergantung pada kepemimpinan kepala sekolah. Karena kepala sekolah sebagai pemimpin di lembaganya, maka dia harus mampu membawa lembaganya kearah tercapainya tujuan yang telah ditetapkan, dia harus mampu melihat adanya perubahan serta mampu melihat masa depan dalam kehidupan globalisasi yang lebih baik. Kepala sekolah harus bertanggung jawab atas kelancaran dan keberhasilan semua urusan pengaturan dan pengelolahan secara formal kepada atasannya atau informal kepada masyarakat yang telah menitipkan anak didiknya.

Keberhasilan sekolah juga tidak terlepas dari kepala sekolah yang efektif, adapun kepala sekolah yang efektif menunjukkan kualitasnya dengan cara sebagaimana 
dikemukakan oleh Sorenson \&. Goldsmith (2009, p.58) sebagai berikut. "(1) establishes a visible presence in the school. (2) monitors teachers and students; (3) communicates a vision of school goals and objectives; (4) fosters an open and positive school culture and climate; (5) serves as an instructional expert available to faculty and staff; (6) develops a safe and orderly learning environment; (7) facilitates an instructional and curricular program that promotes student archievement; (8) establishes high organizational expectations; (9) initiates a professional development program; (10) Implements ongoing evaluation of all personed; (11) aligns curricular and strategic plans to enhance teaching and learning"

Tetapi kenyataan di lapangan untuk membuat suatu pendidikan yang bermutu banyak sekali masalah yang terjadi di SMP 1 Cilawu Kabupaten Garut kepala sekolah dihadapkan ke berbagai permasalahan yang tidak sedikit diantaranya adalah dalam merencanakan program kepala sekolah terkadang kurang berperan aktif, kurangnya informasi tentang pengembangan profesi terhadap pendidik dan tenaga kependidkan, dalam mengorganisasikan sekolah dan monitoring program kepala sekolah kurang berperan aktif.

Masalah sarana dan prasarana juga dihadapi oleh sekolah sehingga dalam proses belajar mengajar kurang maksimal, dalam monitoring dan evaluasi kurang tepat mengidentifikasi penyebab turunnya mutu pendidikan dalam nilai hasil UAN, adanya pendidik dan tenaga kependidikan yang kurang disiplin kerja, kenakalan peserta didik termasuk dalam masalah anggaran yang masih dirasakan tidak seimbang dengan kebutuhan.

Selain permasalahan di atas masih ada lagi beberapa permasalahan lain yang dihadapi kepala sekolah di SMP 1 Cilawu Garut yaitu adanya kekeliruan dalam penempatan tugas tenaga kependidikan seperti menempatkan seseorang yang bu-kan ahlinya sehingga dalam mengemban tugasnya kurang maksimal, selain itu kurangnya keberanian kepala sekolah untuk mengajukan perbaikan sarana dan prasarana yang menunjang lancarnya proses kegiatan bel- ajar mengajar, kemudian koordinasi antara kepala sekolah dengan pendidik dan tenaga kependidikan terkadang terjadi perbedaan pendapat sehingga menimbulkan sebuah ketidaknyamanan dalam mengemban tugas.

Peranan/role merupakan konsep yang tidak bisa dilepaskan dari status, kedudukan dan posisi seseorang. Antara peranan dan status ibarat dua sisi mata uang yang sama, oleh karena itu kita tidak bisa mengerti status tanpa peranan, dan sebaliknya. Robbins (2001, p.227) mendefinisikan peran sebagai " a set of expected behavior patterns attributed to someone occupying a given position in a social unit", sedangkan menurut Veitzhal Rivai (2004, p.148), "peran atau peranan dapat diartikan sebagai perilaku yang diatur dan diharapkan dari seseorang dalam posisi tertentu". Berdasarkan pengertian tersebut, maka dapat disimpulkan bahwa peranan dalam konteks organisasi adalah perilaku yang harus dilakukan oleh seseorang berdasarkan kedudukan, status, dan posisi tertentu yang dimiliki dalam suatu organisasi.

Wahjosumidjo (2003, p.83) bahwa "Kepala sekolah dapat didefinisikan sebagai seorang tenaga fungsional guru yang diberi tugas untuk memimpin suatu sekolah di mana diselenggarakan proses belajar mengajar, atau tempat di mana terjadi interaksi antara guru yang memberi pelajaran dan murid yang menerima pelajaran". Dalam penjelasan di atas, maka dapat disimpulkan bahwasannya posisi kepala sekolah menentukan arah suatu lembaga, kepala sekolah merupakan pengatur dari program yang ada disekolah. Karena nantinya diharapkan kepala sekolah akan membawa spirit kerja guru dan membangun kultur sekolah dalam peningkatan mutu pendidikan.

Gorton \& Alston (2010, p.7) mengemukakan bahwa "manager are people who do things right, are leaders all people who do the right things and good managers handle the routine daily jobs". Sebagai seorang manajer tentunya harus memiliki berbagai keterampilan tertentu sebagaimana dikemukakan Handoko (2003, p.36) adalah: “(a) keteram- 
pilan konseptual, yaitu kemampuan mental untuk mengkoordinasikan seluruh kepentingan dan kegiatan organisasi; (b) keterampilan kemanusiaan, kemampuan bekerja dengan memahami dan memotivasi orang lain baik sebagai individu maupun kelompok; (c) keterampilan administratif, yaitu dengan perencanaan, pengorganisasian, penyusunan kepegawaian dan pengawasan; (d) keterampilan teknik, yaitu kemampuan menggunakan peralatan, prosedur, teknik-teknik dari suatu bidang tertentu seperti mesin, dan sebagainya".

Kepala sekolah sebagai manajer pada intinya adalah melaksanakan fungsi manajemen sebagaimana yang dikemukakan oleh Terry (1997, p.4) yang menjelaskan pengertian manajemen adalah sebagai berikut "Management is a distinc process consisting of planning, organizing, actualiting, and controlling, performed to determine and accomplish atated objectives by the use of human beings and other resources. Manajemen adalah proses yang jelas yang meliputi perencanaan, pengorganisasian, penggerakan dan pengawasan yang diselenggarakan untuk mencapai tujuan yang telah ditetapkan dengan potensi manusia dan sumberdaya lainnya. Pendapat lain yang mengemukakan tentang fungsi-fungsi manajemen diungkapkan oleh Robbins \& De Cenzo (1995, p.6) bahwa fungsi-fungsi manajemen meliputi planning, organizing, leading, and controlling.

Newman (Manullang, 2006, p.39) menyatakan, "Planning is deciding in advance what is to be done". Perencanaan adalah penentuan terlebih dahulu apa yang akan dikerjakan. Sedangkan Daryanto (2005, p.82) "menyebutkan perencanaan pada dasarnya menjawab pertanyaan apa yang harus dilakukan, bagaimana melakukan, dimana dilakukan, siapa yang harus melakukan, dan kapan pekerjaan itu dilakukan". Sedangkan menurut Lunenburg \& Ornstein $(2000$, p.6) "planning involves developing an outline of things that must be accomplished and the methods for accomplishing them. The activity attemps to forecast future actions and directions of the organization". Dari beberapa pendapat di atas dapat disimpulkan bahwa pengertian peren- canaan yaitu sebagai proses penyusunan dan penentuan tujuan serta cara-cara yang harus dilakukan. Demikian halnya perencanaan dalam bidang pendidikan. Pada tahap perencanaan, sekolah merencanakan kegiatan-kegiatan dan cara-cara apa yang harus dilakukan untuk mencapai tujuan yang telah ditetapkan.

Pengorganisasian merupakan aktivitas menyusun dan membentuk hubungan kerja antara orang-orang sehingga terwujud suatu kesatuan. Manullang (2006, p.59) mengemukakan bahwa "pengorganisasian berasal dari kata organon, dan dalam bahasa Latin organum yang berarti alat, bagian, anggota, atau badan", pendapat lain dikemukakan oleh Kowalski (2010, p.28) bahwa "principals organize by bringing together and arranging people, materials and other resources to ensure attainment of the school's goal". sementara Usman (2006, p.128) mengemukakan bahwa "organisasi merupakan proses kerjasama dua orang atau lebih untuk mencapai tujuan organisasi secara efektif efisien". Definisi ini bersifat umum berlaku bagi semua organisasi termasuk organisasi pendidikan. Setiap organisasi memiliki tiga komponen yaitu kerjasama, adanya dua orang atau lebih dan tujuan yang hendak dicapai.

Berkaitan dengan bidang pendidikan di sekolah, pengorganisasian merupakan aktivitas menyusun dan membentuk hubungan kerja antara personil sekolah dan hubungan antara sumber daya sekolah lainnya sehingga terbentuk suatu kesatuan kerja untuk mencapai tujuan pendidikan. Dalam hal ini Suryobroto (2004, p.24) mendefinisikan pengorganisasian di sekolah sebagai "keseluruhan proses untuk memilih orang-orang (guru dan personil sekolah lainnya) serta mengalokasina sarana prasarana untuk tugas, tanggung jawab, wewenang dan mekanisme kerja sehingga menjamin tercapainya tujuan sekolah"

Usman (2005, p.22) menyebutkan bahwa langkah ketiga dari manajemen adalah penggerakan. Penggerakan adalah "serangkaian kegiatan yang dilakukan setelah perencanaan untuk mencapai tujuan tertentu secara efektif dan efisien". Peng- 
gerakan merupakan kegiatan membimbing anak buah dengan memberi perintah, petunjuk, mendorong semangat kerja, menegakkan disiplin, dan memberikan berbagai usaha lain agar mereka bekerja mengikuti tujuan yang telah ditetapkan sebelumnya. Sementara itu Bateman \& Zeithaml (1990, p.19) bahwa: "illustrated that the leading function focuses on the efforts of the manager to stimulate high performance among employees, and this activity involves directing, motivating, and communicating with employees".

Controlling merupakan fungsi terakhir manajemen, berkaitan dengan penilaian terhadap keberhasilan atau kegagalan sesuatu. Terry (Ticoalu, 2005, p.232) mengemukakan bahwa "Pengawasan adalah mengevaluasi pelaksanaan kerja, jika perlu memperbaiki apa yang sedang dikerjakan untuk menjamin tercapainya hasil sesuai rencana. Mohanty (2005, p.275) mengemukakan bahwa "supervision is a planned programme for the improvement of instruction".

Manullang (2006, p.12) menjelaskan pengawasan atau disebut pengendalian adalah "salah satu fungsi manajemen yang berupa pengadaan penilaian, bila perlu mengadakan koreksi sehingga apa yang dilakukan bawahan dapat diarahkan dengan benar kearah tercapainya tujuan yang telah digariskan". Dalam pengawasan atasan memeriksa, mencocokan, mengusahakan agar kegiatan yang dilaksanakan sesuai dengan rencana.

Dari penjelasan di atas, maka kepala sekolah sebagai manajer sekolah mengatur dan mengelola segenap potensi sekolah melalui tahapan merencanakan, mengorganisasikan, menggerakan, dan mengawasi potensi-potensi tersebut guna mendukung tercapainya tujuan pendidikan.

Rumusan permasalahan dalam penelitian ini adalah Bagaimana kepala sekolah dalam perencanaan, pengorganisasian, penggerakan, dan monitoring/evaluasi program dalam meningkatkan mutu pendidikan di SMP 1 Cilawu Garut, dan Apa saja kendala yang dihadapi seorang kepala sekolah di SMP 1 Cilawu Garut dalam meningkatkan mutu pendidikan di sekolah. Berdasarkan permasalahan tersebut tujuan penelitian ini adalah untuk mendeskripsikan strategi kepala sekolah dalam merencanakan, mengorganisasikan, penggerakan, dan monitoring program sekolah untuk meningkatkan mutu pendidikan di SMP 1 Cilawu Kabupaten Garut, dan untuk mendeskripsikan apa saja yang menjadi penghambat dalam peningkatan mutu di SMP 1 Cilawu Garut.

\section{Metode Penelitian}

Jenis, Waktu, Tempat dan Subjek Penelitian

Penelitian ini merupakan studi kasus dengan pendekatan kualitatif yang memfokuskan pada bagaimana peran kepala sekolah sebagai seorang manajer dalam meningkatkan mutu pendidikan di SMP 1 Cilawu Kabupaten Garut. Walaupun demikian penulis tidak mengabaikan datadata kuantitatif yang diperlukan untuk lebih menggambarkan situasi dan konsisi objek penelitian. Pendekatan kualitatif digunakan dengan alasan penelitian ini berusaha mengungkap kenyataan yang ada di lapangan tentang peran kepala sekolah sebagai manajer serta dapat dipahami secara mendalam, sehingga pada akhirnya dapat diperoleh temuan penelitian

Penelitian ini dilakukan SMP 1 Cilawu, Jalan Genteng - Cilawu Garut. Waktu penelitian ini dilaksanakan pada bulan Maret - Mei 2013

Subjek penelitian ini informan yang memberikan informasi yang berkaitan dengan peran kepala sekolah sebagai manajer. Subjek penelitian ini adalah kepala sekolah, guru, dan tenaga kependidikan SMP 1 Cilawu Garut yang berjumlah 11 orang. Pemilihan informan dalam penelitian ini diperoleh dengan teknik snowball sampling. Penelitian ini mengutamakan data langsung dari informan dan observasi yang dilakukan di lapangan. Objek penelitian ini adalah aktivitas yang dilakukan kepala sekolah sebagai manajer.

\section{Teknik Pengumpulan Data}

Data penelitian ini diperoleh dengan cara peneliti melakukan wawancara dengan melakukan pertemuan langsung de- 
ngan kepala sekolah, guru yang berjumlah 7 orang (OD, W, MY, AFH, TS, D, DHT), tenaga kependidikan 2 orang $(\mathrm{SM}, \mathrm{R})$, dan perwakilan komite sekolah (DMR) dengan memfokuskan pada materi yang bersangkutan dengan penelitian yang sedang berlangsung diantaranya adalah tentang kurikulum yang dilaksanakan pada saat ini, peran kepala sekolah dalam melaksanakan tugas dan sejarah dari Objek yang diteliti. Metode pengumpulan data ini berfungsi sebagai penggali informasi berupa pertanyaan-pertanyaan yang berkaitan dengan peran kepala sekolah sebagai manajer. Dalam penelitian ini digunakan studi dokumentasi untuk memperoleh data gambaran umum tentang sejarah SMP 1 Cilawu, susunan organisasi, prestasi yang telah dicapai, dan rencana pengembangan sekolah.

Teknik Analisis data

Dalam penelitian ini dianalisiskan dengan cara mereduksi data, display data dan mengambil kesimpulan dari data yang terkumpul tersebut. Reduksi data dilakukan dengan proses pemilihan, pemuatan perhatian pada penyederhanaan atau peningkatan data dalam bentuk uraian atau laporan yang terinci. Reduksi data dimulai dengan membuat rangkuman dari setiap data agar mudah dipahami, membuang data yang dianggap tidak penting serta keseluruhan rangkaian ini kemudian dikelompokan berdasarkan katagori dari permasalahan yang diteliti (lihat tabel reduksi data kepala sekolah. Display data adalah upaya untuk menyajikan data dengan cara melihat gambaran keseluruhan atau bagian tertentu dari data penelitian untuk mempermudah dalam membaca data maka data yang telah direduksi kemudian disajikan dengan cara menggabungkan informasi yang tersusun dalam satu bentuk yang mudah dilihat untuk dikaji. Mengambil kesimpulan adalah upaya untuk mencari makna terhadap data yang dikumpulkan dengan cara mmpelajari pola, tema, persamaan, perbedaan, dan hal yang paling banyak timbul.

\section{Hasil Penelitian dan Pembahasan}

Hasil Penelitian

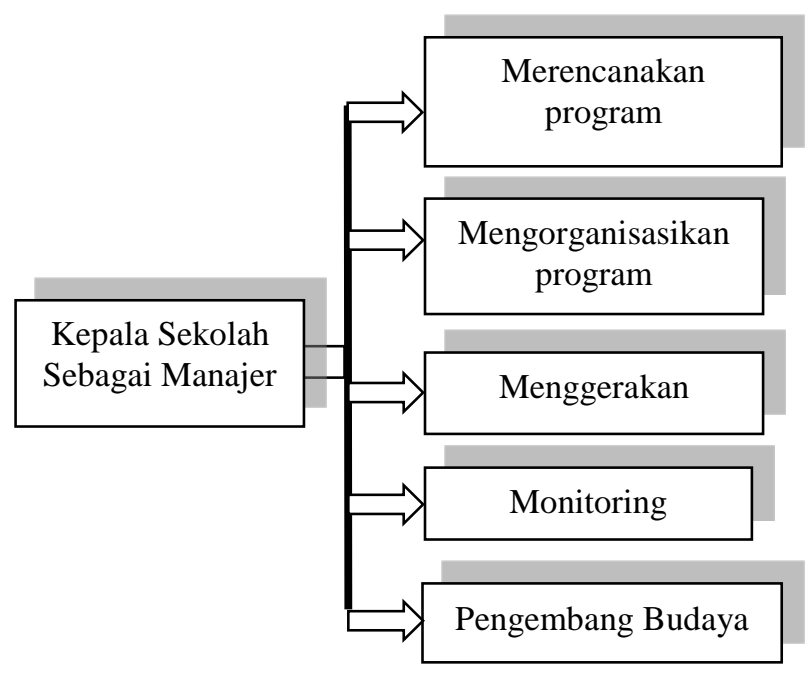

Gambar 1. Peran Kepala Sekolah di SMP 1 Cilawu

Berdasarkan gambar di atas, diperoleh hasil bahwa kepala sekolah sebagai manajer meliputi merencakanan program. Dalam merencanakan program, kepala sekolah memulai dari: (1) merencanakan SDM dengan merinci kebutuhan tenaga pendidik yang akan menjalankan tugas dalam mengajar; (2) merencakanan kebijakan seperti program kepala sekolah serta kurikulum yang akan dijalankan di sekolah ini; (3) dalam menyusun kebijakan, kepala sekolah melibatkan guru dan tenaga ahli dengan melewati beberapa tahapan seperti mengadakan beberapa kali pertemuan dengan para PKS, guru, komite sekolah dan stake holder lainnya seperti pengawas; (4) Berdasarkan kebijakan kepala sekolah, di SMP 1 Cilawu ada penambahan mata pelajaran yaitu bimbingan dan konseling dengan waktu 2 jam pelajaran/minggu.

Peran kepala sekolah yang kedua adalah mengorganisasikan program yaitu dengan cara membuat sebuah struktur organisasi sekolah seperti adanya keterlibatan orang tua melalui komite sekolah dengan melengkapi sarana yang dibutuhkan oleh sekolah, memantau pembelajaran di kelas, pembagian tugas seperti adanya PKS dan TU sesuai kemampuan guru baik di tingkat kelas maupun keterampilan yang 
mereka miliki, membentuk kepanitiaan dalam menghadapi lomba atau pelatihan.

Peran kepala sekolah sebagai manajer yang ketiga adalah penggerakan program yaitu dengan cara menggerakan pendidik dan tenaga kependidikan yang ada seperti dengan memberi contoh yang baik dan tenang dalam bekerja,untuk guru adanya motivasi semangat long life education (guru harus belajar), memotivasi pendidik dan tenaga kependidikan secara moril maupun meteri, peningkatan kesejahteraan, memberikan penghargaan terhadap guru dan kependidikan yang berprestasi, mengikutsertakan guru dalam diklat-diklat, MGMP, memberikan bimbingan kepada tenaga pendidik dalam pembuatan perangkat lunak (RPP, Silabus), memberikan briefing sekaligus mengevaluasi terhadap kinerja pendidik dan tenaga kependidikan pada awal bulan setiap satu bulan sekali, serta memfasilitasi bawahan untuk dapat melaksanakan pengembangan profesi, serta mendukung pendidik atau tenaga kependidikan bagi yang ingin melanjutkan studi dan yang ingin mendapatlan tunjangan sertifikasi.

Peran yang keempat adalah monitoring dan evaluasi yang dilakukan dengan cara melakukan pengawasan baik dalam PBM maupun dalam pencapaian peningkatan mutu pendidikan serta pencapaian nilai UN. Pengawasan dalam PBM dilaksanakan dengan mengacu pada PKB dan PKG serta dilaksanakan oleh tim yang di bentuk oleh kepala sekolah. Pengawasan terhadap peningkatan mutu pendidikan meliputi pengawasan terhadap input (SDM, struktur organisasi, rencana dan program, visi, misi dan tujuan), proses (kinerja dari kepala sekolah), dan output (prestasi sekolah yang dihasilkan setelah proses baik prestasi akademik maupun non akademik. Pengawasan tersebut dilakukan secara berkala yakni pada akhir semester, akhir/awal tahun ajaran baru dengan pelaksanaannya di bantu oleh wakasek, para PKS serta koordinator BK (Bimbingan dan Konseling). Setelah pengawasan apabila ditemukan adanya penghambat baik dari SDM maupun sumber harapan, maka yang dilakukan adalah memberi pengertian secara umum pada rapat pembinaan dewan guru, menggali latar belakang dari masalah, serta mencari solusi untuk pemecahan masalah tersebut.

Peran yang terakhir adalah sebagai pengembang budaya dengan melaksanakan budaya sekolah seperti budaya dalam keagamaan, budaya kedisiplinan, budaya berprestasi serta budaya kebersihan guna meningkatkan mutu pendidikan serta membentuk peserta didik yang berkarakter dan berpegang teguh pada nilai-nilai keagamaan.

Pembahasan

\section{Kepala Sekolah dalam Kegiatan Perencanaan}

Dalam merencanakan sebuah program jangka panjang maupun pendek kepala sekolah selalu memanggil para PKS, wakasek, serta perwakilan dari guru mata pelajaran guna meminta pendapat dan bantuannya dalam menyusun sebuah program tersebut. Adapun program jangka panjang sekolah ini menginginkan supaya sekolah ini menjadi sekolah pelopor dalam bidang olahraga dan seni di kabupaten Garut.

Dalam menyusun sebuah kebijakan, kepala sekolah ada yang membantu yaitu PKS bidang kurikulum. Komite sekolah juga ikut dilibatkan dalam menyusun sebuah kebijakan-kebijakan yang berhubungan dengan siswa dan kontrol anggaran yang diterima oleh sekolah. Komite sekolah aktif dalam mengontrol sekolah hal tersebut dibuktikan dengan sering hadirnya komite sekolah di sekolah dan berdiskusi dengan kepala sekolah dan guru lainnya.

Perubahan pada pengembangan diri ada perampingan jenis pengembangan diri yang pada kepala sekolah sebelumnya cukup banyak tetapi pada saat ini dibatasi karena terlalu banyak menurut kepala sekolah kurang terlalu efektif, pengembangan diri yang sekarang adalah diprioritaskan pada bidang olahraga dan kesenian, bimbingan konseling. Selain itu ada juga pelatihan bahasa inggris untuk siswa dan 
pembentukan siswa yang berkarakter dengan cara adanya bimbingan kegiatan shalat jum'at dan kegiatan keputrian yang dilaksanakan pada satu jam sebelum shalat jum'at.

\section{Kepala Sekolah dalam Kegiatan Pengorganisa- sian}

Peranan kepala sekolah sebagai organisator di SMP 1 Cilawu diperoleh hasil adanya keterlibatan orang tua melalui komite sekolah dengan melengkapi sarana yang dibutuhkan oleh sekolah, memantau pembelajaran di kelas, pembagian tugas sesuai kemampuan guru baik di kelas maupun keterampilan yang mereka miliki, membentuk kepanitiaan dalam menghadapi lomba.

Struktur organisasi di sekolah dipandang sudah sesuai dengan kebutuhan karena dalam organisasi sekolah merupakan hak prerogratif kepala sekolah sesuai kebutuhan kepala sekolah dalam menjalankan tugas. Selama kepemimpinan kepala sekolah yang sekarang belum ada perekrutan pendidik apalagi dengan adanya sertifikasi guru saat ini, dari yang sebelumnya minimal jam mengajar 18 jam perminggu menjadi 24 jam perminggu sehingga untuk menutupi jumlah yang 24 jam perminggu harus mengajar di sekolah lain dan berpindah mata pelajaran sesuai dengan ijazahnya sehingga terjadi kelebihan pendidik pada bidang studi tertentu.

\section{Kepala Sekolah dalam Kegiatan Penggerakan}

Peranan kepala sekolah sebagai penggerak di SMP 1 Cilawu diperoleh hasil sebagai berikut: untuk guru adanya motivasi semangat life long education (guru harus belajar), peningkatan kesejahteraan dan adanya kesempatan untuk bertanya dalam suasana yang menyenangkan, mendatangkan narasumber untuk membimbing guru dalam pembuatan tulisan ilmiah, mengikuti seminar dan lainnya seperti mengikutsertakan guru dalam MGMP, serta mengefektifkan tutur sebaya.

Dalam membina pendidik, kepala sekolah mengadakan MGMP tingkat rayon dan sekolah yang mana ada 12 orang ma- sing-masing satu mata pelajaran dalam satu bulan yang diikutsertakan dalam MGMP tingkatrayon dan sekolah. Sebulan sekali diadakan briefing dengan guru dan dengan staf dalam rangka mengevaluasi kinerja guru selama satu bulan. Dalam membina pendidik dan tenaga kependidikan, kepala sekolah selalu mengadakan pengarahan terhadap pendidik dan tenaga kependidikan dalam rangka meningkatkan mutu pendidikan dan memperjelas tugas dari masing-masing, contoh nyata kepala sekolah dalam membina pendidik yaitu dengan adanya in house training, mengikuti MGMP setiap bulan baik tingkat rayon maupun kabupaten, sedangkan dari tenaga kependidikan seperti di bagian TU dan perpustakaan guna meningkatkan kinerja tenaga kependidikan diadakan pelatihan penataan ruang perpustakaan supaya tertata rapih dan siswa betah apabila sedang membaca di perpustakaan.

Peningkatan kesejahteraan termasuk dalam penggerakan yang dilakukan oleh kepala sekolah akan tetapi ada sebagian guru yang mengatakan bahwa kesejahteraan secara finansial belum kena sasaran yang diterapkan sedangkan secara non finansial sangat baik dengan kenyamanan yang diberikan oleh kepala sekolah dan jaminan ketenagaan.

\section{Kepala Sekolah dalam Kegiatan Montoring}

Peranan kepala sekolah sebagai montor di SMP 1 Cilawu adalah dengan adanya monitoring dari seluruh perencanaan, pengorganisasian, penggerakan dimulai dari pengawasan pembuatan program semester, pembuatan RPP, pelaksanaan PBM baik langsung maupun tidak langsung. Semua dievaluasi secara periodik minimal pada akhir semester atau pada tahun ajaran baru. Evaluasi tersebut dibantu oleh PKS dan guru lainnya yang dianggap mampu dalam menjalankan tugas sebagai pengevaluasi.

Dalam pencapaian target UN, kepala sekolah selalu memonitoring dalam persiapan UN, strategi yang dirancang guna UN bisa sukses, contoh kepala sekolah memberikan motivasi kepada peserta di- 
dik, kemudian membuat program bimbingan belajar dalam menghadapi UN, program PBM pada mata pelajaran yang ada pada UN saja.

Kepala sekolah selalu memonitoring semua kegiatan akademik di sekolah dengan dibantu oleh para PKS apalagi dalam dua tahun kebelakang hasil UN di sekolah ini menurun. Kepala sekolah menginginkan hasil UN di tahun ini meningkat dari tahun sebelumnya, adapun cara yang dilakukan oleh kepala sekolah adalah memberi tugas kepala pendidik supaya mengadakan jam tambahan untuk mata pelajaran yang ada pada UN supaya peserta didik bisa lebih memahami mata pelajaran tersebut yang nantinya berimbas pada nilai hasil UN akan meningkat.

\section{Kepala Sekolah Sebagai Pengembang Budaya}

Selain keempat peran yang dijalankan oleh kepala sekolah di atas, kepala sekolah mempunya strategi lain dalam menjalankan tugasnya sebagai manajer di SMP 1 Cilawu Garut, strategi tersebut adalah menjadi seorang pengembang budaya yakni membudayakan untuk berdisiplin, membiasakan untuk mencintai kebersihan, membudayakan berprestasi, serta budaya keagamaan yang dilaksanakan dengan bimbingan kegiatan shalat jum'at dan keputrian yang dilaksanakan pada waktu satu jam sebelum waktu shalat jum'at.

\section{Simpulan dan Saran}

Simpulan

Peran kepala sekolah dalam merencanakan program, dimulai dari merencanakan kebutuhan SDM yang akan menjalankan tugas, merencanakan kebijakan berupa program kepala sekolah dan kurikulum yang akan dijalankan di sekolah. Dalam perencanaan ini kepala sekolah selalu melibatkan guru, PKS dan komite sekolah.

Peran kepala sekolah dalam mengorganisasikan program yaitu membuat struktur organisasi sekolah yang melibatkan orang tua melalui komite sekolah, melengkapi sarana yang dibutuhkan oleh sekolah, pembagian tugas seperti adanya
PKS dan TU sesuai sesuai kemampuan guru baik di tingkat kelas maupun keterampilan yang mereka miliki. Dalam mengorganisasi kepala sekolah tidak bekerja sendiri tetapi dibantu oleh para pembantu kepala sekolah dan komite sekolah.

Peran kepala sekolah dalam menggerakan pendidik dan tenaga kependidikan dengan member contoh yang baik dan tenang dalam bekerja, memotivasi pendidik dan tenaga kependidikan secara moril maupun materi, peningkatan kesejahteraan, memberikan penghargaan terhadap personil yang berprestasi, mengikutsertakan dalam diklat-diklat, MGMP, memfasilitasi bawahan dalam melaksanakan pengembangan profesi, mendukung pendidik bagi yang ingin melanjutkan studi, serta bagi guru senior adanya motivasi semangat life long education.

Peran kepala sekolah dalam monitoring dan evaluasi yang meliputi monitoring terhadap siswa dari mulai proses seleksi sampai selesai, prestasi sekolah baik akademik maupun non akademik, pengawasan terhadap PBM dengan instrumen mengacu pada PKG dan PKB, memantau pembelajaran di kelas. Setelah melakukan monitoring, apabila ditemukan adanya penghambat baik dari SDM maupun dari prestasi sekolah, maka kepala sekolah memberi pengertian secara umum pada rapat pembinaan dewan guru, menggali latar belakang dari masalah, serta mencari solusi untuk pemecahan masalah tersebut.

Hambatan yang dialami kepala sekolah dalam mengoptimalkan perannya sebagai manajer antara lain: (a) disiplin kerja dan belajar masih kurang. (b) masih kurang terjalin komunikasi antara kepala sekolah dengan guru, (c) menerapkan dana BOS yang aturannya sudah ditentukan sementara kebutuhan sekolah tidak sesuai dengan aturan dana BOS, (d) menghadapi masukan yang datang dari stake holder lainnya yang terkadang stake holder tersebut keinginannya itu harus dituruti oleh pihak sekolah.

Pengembang budaya. Melaksanakan budaya sekolah seperti budaya keagamaan, budaya berdisiplin, budaya berprestasi, 
serta budaya kebersihan guna meningkatkan mutu pendidikan serta membentuk peserta didik yang berkarakter dan berpegang teguh pada nilai-nilai keagamaan.

Saran

Komunikasi antara kepala sekolah, guru, komite dan stake holder lainnya harus terjalindengan baik sehingga setiap informasi yang disampaikan oleh kepala sekolah mudah dipahami, dan kepala sekolah hendaknya membuat perencanaan yang matang demi tercapainya tujuan yang akan dicapai.

Kepala sekolah harus lebih teliti dalam membuat susunan organisasi, memberikan tugas kerja bagi pendidik dan tenaga kependidikan serta dalam pemeliharaan sarana prasarana di sekolah.

Kepala Sekolah harus memberi contoh yang baik bagi para personilnya baik dalam menjalankan tugas maupun dalam memberikan tugas kepada personilnya.

Dalam rangka pengawasan kepala sekolah harus sering memantau PBM dan pencapaian UN dengan memberi tugas kepada personil yang dipercaya mampu menjalankan tugas tersebut sehingga hasil dari pemantauan tersebut dapat segera ditindaklanjuti apabila ada sesuatu yang menyimpang.

\section{Daftar Pustaka}

Daryanto, H.M. (2006). Administrasi pendidikan. Jakarta: Rineka Cipta

Gorton, R.A \& Alston, J.A. (2010). School leadership $\mathcal{E}$ administration: Important concepts, casestudies, $\mathcal{E}$ simulations. New York: McGraw-Hill Companies, Inc
Handoko, H. (2003). Manajemen. Yogyakarta: BPFE

Kowalski, T.J (2010). The School Principal. New York: Routledge

Lunenburg, F.C \& Ornstein, A.C. (2000). Educational administration: Consepts and practices. Belmont: Wadsworth Thomson Lerning

Manullang, M. (2006). Dasar-dasar manajemen. Yogyakarta: Gadjah Mada University Press

Mohanty, J. (2005). Educational administration, supervision and school management. New Delhi: Deep \& Deep Publications Pvt. Ltd.,

Robbins, S.P. (2001). Organizational behavior (9th ed.). Upper Saddle River: Prentice Hall.

Robbins, S.P \& De Cenzo. (1995). Fundamentals of management. Upper Saddle River: Prentice Hall.

Sorenson, R.D \& Goldsmith L.M. (2009). The principal's guide to managing school personnel. Thousand Oaks, CA: Corwin

Suryobroto, B. (2004). Manajemen pendidikan di sekolah. Jakarta: Rineka Cipta.

Terry, G.R. \& Rue, L.W. (2010). Dasar-dasar manajemen. Jakarta: Bumi Aksara.

Terry, G.R. (1997). Prinsip-prinsip manajemen. Jakarta: Bumi Aksara.

Usman, H. (2006). Manajemen: Teori, praktik, dan riset pendidikan. Jakarta: Bumi Aksara.

Wahjosumidjo. (2003). Kepemimpinan kepala sekolah. Jakarta: Raja Grafindo Persada 